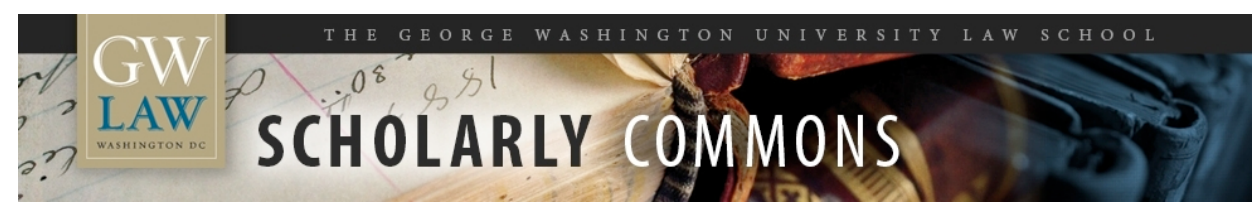

\title{
Child Testimony and the Right to Present a Defense
}

Stephen A. Saltzburg

George Washington University Law School, ssaltz@law.gwu.edu

Follow this and additional works at: https://scholarship.law.gwu.edu/faculty_publications

Part of the Law Commons

\section{Recommended Citation}

Saltzburg, Stephen A., Child Testimony and the Right to Present a Defense (2013). 28 Crim. Just. (2013) ; GWU Law School Public Law Research Paper No. 2013-142; GWU Legal Studies Research Paper No. 2013-142. Available at SSRN: http://ssrn.com/abstract=2663645

This Article is brought to you for free and open access by the Faculty Scholarship at Scholarly Commons. It has been accepted for inclusion in GW Law Faculty Publications \& Other Works by an authorized administrator of Scholarly Commons. For more information, please contact spagel@law.gwu.edu. 


\section{Child Testimony and the Right to Present a Defense}

\section{BY STEPHEN A. SALTZBURG}

$\mathrm{H}$ arris v. Thompson, 698 F.3d 609 (7th Cir. 2012), is a reminder of how important a child's testimony can be in a criminal prosecution. Trial judges generally have considerable discretion in ruling on the competency of child witnesses, but Harris indicates that the Sixth Amendment compulsory process right and the due process right to present a defense can limit that discretion to some extent.

Nicole Harris was convicted of murdering her four-year-old son. She lost her direct appeal to an Illinois appellate court and sought federal habeas corpus relief. A district judge denied her petition, but the Seventh Circuit reversed and held that Harris's Sixth Amendment right to present a defense was violated by the state trial judge's exclusion of the testimony of the defendant's other son, who was five years old when his brother died and six at the time of trial. The court also held that defense trial counsel's serious errors in the competency hearing that resulted in the son's exclusion deprived Harris of the effective assistance of counsel, because counsel was not ready for the hearing, had not interviewed the son, and did not secure the presence of a witness who would have shown that the son's recollections of what happened where consistent and credible. The discussion here is limited to the admissibility of the child's testimony and does not address the scope of habeas corpus or the ineffective assistance part of the case.

\section{The Facts}

The 23-year-old Harris lived in a Chicago apartment with her boyfriend, Sta-Von Dancy, and their two sons, five-year-old Diante and four-year-old Jaquari. One afternoon Harris and Dancy went to the laundromat across the street, left the boys alone for approximately 40 minutes, and told them not to leave the apartment. Harris returned to check on the boys while clothes were drying and found Diante in the hallway and Jaquari playing outside.

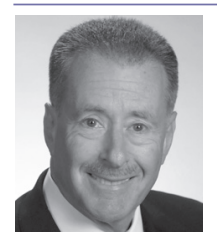

STEPHEN A. SALTZBURG is the Wallace and Beverley Woodbury University Professor at George Washington University School of Law in Washington, D. C. He is a past chair of the Criminal Justice Section and a regular columnist for Criminal Justice magazine. He is also author of the book, Trial Tactics, Third Edition (American Bar Association 2013), an updated and expanded compilation of his columns.
She yelled at the children and ordered them to go to their bedroom, where Jaquari began crying. Harris returned to the laundromat and Dancy went back to the apartment and took a nap after speaking to the children in their bedroom.

Dancy awakened to find Jaquari lying on the bedroom floor, unresponsive and blue in the face with an elastic band from a fitted sheet wrapped nearly 10 times around his neck. After Dancy attempted unsuccessfully to resuscitate Jaquari, he lifted the child and ran outside, where he met Harris returning again from the laundromat. With Harris driving their car, Dancy continued CPR in in the back seat, and they called 911. An ambulance met them and took Jaquari to a hospital. They went back to the apartment for Diante, and returned to the hospital to hear Jaquari pronounced dead.

Chicago police officers arrived and questioned Harris and Dancy, who agreed to accompany officers to the police station for further questioning. Detectives interviewed the two separately before continuing their investigation at the apartment, where forensic technicians collected the elastic band and the bed sheet along with a telephone cord that they suspected might have been used to strangle Jaquari. The detectives, who learned from neighbors that Harris had struck her children with a belt that day, returned to the station and confronted her with discrepancies between what she and the neighbors said. The detectives would later claim that after about 15 minutes of questioning, Harris started to cry and burst out with "I wrapped the phone cord around Jaquari's neck and then I wrapped the elastic band from the bed sheet around his neck to make it look like an accident." (Id. at 614.)

After the detectives read her Miranda rights, Harris recanted her initial unwarned confession. She was kept overnight in a holding cell, took an inconclusive polygraph examination, and then confessed again and said that she strangled Jaquari with the elastic band. A prosecutor came to the station and obtained a videotape of Harris's confession, in which she stated that she had struck Jaquari with a belt when she came home from the laundromat and wrapped the band around his neck to stop him from crying before returning to the laundromat. The second confession made no mention of the phone cord, which an autopsy determined was not used to cause Jaquari's death.

\section{The Trial}

At trial, it was agreed that Jaquari died from asphyxiation as a result of having the elastic band from a fitted bed sheet wound around his neck, and that Diante was in the top bunk of the bed he shared with his brother when Jaquari died. The prosecution relied on the second confession and sought to prove that Harris became angry when Jaquari would not stop crying and strangled him with the elastic band. The 
defense theory was that Jaquari accidentally asphyxiated himself while Harris was at the laundromat.

The state relied heavily on Harris's videotaped confession as well as the testimony of the doctor who conducted the autopsy. The doctor originally concluded that the death was an accident, but changed his opinion after learning of Harris's confession and that traces of blood were found on the linen on Jaquari's bed.

Harris testified on her own behalf. She admitted scolding the children and sending them to their room, but denied striking them. She testified that when she came back from the laundromat the second time she met Dancy outside holding Jaquari. Harris, who stated on the videotape that she had been treated well by police who made no promises or threats, also testified that she made the videotaped confession after 27 hours of coercive interrogation in which she was deprived of food and water, threatened, and promised leniency if she cooperated.

Dancy testified that he had previously seen Jaquari wrapping the sheet's elastic band around his neck. Other family members testified that Jaquari was curious and playful, including an aunt who testified that she once saw the boy put a plastic laundry bag over his face.

Diante, who was six at the time of the trial, was the key witness for the defense but was not permitted to testify.

\section{Diante's Interview}

An investigator, Dr. Ale Levy with the Child Advocacy Center, interviewed Diante the day after the death with a police detective present taking notes. The center partners with the Chicago Police Department, the state's attorney, and the Department of Child and Family Services. The officer's notes indicated that Diante contradicted Harris as to her claim not to have hit Jaquari and said that Harris spanked both boys when she found them outside the apartment and caused Jaquari to bleed when she hit him with a belt on the leg. The notes also indicated, however, that Diante clearly described an accident in which "Jaquari was playing [and] wrapped elastic around neck from blue sheet," and Diante was "playing Spiderman game" and "couldn't help Jaquari get out of his sheet." (Id. at 616 (alteration in original).)

\section{Competency Hearing}

The prosecution sought to exclude Diante as a witness. The trial judge conducted a competency hearing and began by misapplying Illinois law, which imposes the burden of showing incompetence on the party challenging a witness, and imposing the burden on the defense to show Diante's competence.

Defense counsel called Diante as a witness and had him spell his name, state his age, give his birthday, list the cities where he had lived, name his teacher, and describe the color of certain objects. The trial judge asked him if he knew the difference between a truth and a lie and Diante said, "Telling a lie, you might get in trouble. Telling the truth, you might get a star." (Id. at 617.)

Diante said that on the day Jaquari died, Diante was with Jaquari and was "Playing my game." He said, "Jaquari was playing with that string and wrapping it around his neck." (Id.) He testified that the string was the band from the blue sheet and that only the two boys were in the room when Jaquari wrapped the sheet's elastic around his neck. Diante answered "yes" when asked by the prosecutor if he remembered telling a Department of Child and Family Services investigator that he was asleep when Jaquari "got hurt."

Defense counsel asked Diante whether he knew "the difference between real people and cartoons." (Id.) Diante said he did and named "Scooby-Doo, Tom and Jerry" as examples of cartoons. The prosecutor picked up this line of questioning but, as the Seventh Circuit described the prosecutor's questions, "the prosecutor shifted to use the word 'real' differently" and "[t]his shift caused some confusion":

Q: Okay. Now, you were talking about some cartoons a couple of minutes ago. You were talking about Scooby-Doo, and cartoons and real things, right?

A: (Nodding.)

Q: Do you think Spiderman is real?

A: Yes.

Q: And have you ever seen Spiderman in person?

A: Yes.

Q: Okay. And what did you say to Spiderman when you saw him in person?

A: Nothing.

Q: You didn't say anything to him?

A: (Nodding.)

Q: Have you ever seen Scooby-Doo?

A: No.

Q: Okay. Is Scooby-Doo real?

A: No.

Q: Okay. Scooby-Doo is what?

A: A movie.

Q: Okay. And how about The Hulk? Is The Hulk real or is he something else?

A: Something else.

Q: Okay. Let's see. How about Santa Claus, is Santa Claus real?

A: Yes.

Q: And have you ever seen Santa Claus in person?

(Id.) 
The prosecutor also had Diante say that he believed the tooth fairy was real. The Seventh Circuit concluded that Diante thought the prosecutor was asking whether Spiderman and Santa Claus were animated or human characters, not cartoons. If so, his answers were true and were in part explicable by Dancy's trial testimony that Diante was familiar with Spiderman live-action films. The prosecutor also asked Diante about Jaquari:

Q: You told me earlier that you have seen Jaquari in heaven, right?

A: Yes.

Q: And do you remember the last time you saw Jaquari in heaven?

A: Where I was in the rainbow.

Q: When you were in the what?

A: In the rainbow.

Q: "In the rainbow"? You were in the rainbow?

A: Uhn-uhn. No, in the car.

Q: $\mathrm{Oh}$, in the car. And you saw Jaquari in heaven then?

A: (Nodding.)

(Id. at 618.)

The Seventh Circuit, relying on the conclusions of Dr. Robert Galatzer-Levy, a child psychiatrist who conducted a competency assessment of Diante six months after the trial, found that Diante was saying "limo" rather than "rainbow." The court also observed that during Galatzer-Levy's assessment, Diante described a church as a "church with heaven" and a courtroom as a "church with the judge." (Id.) The Seventh Circuit found that this was consistent with Diante's testimony that other living family members were present "in heaven" in the following exchange that took on great importance for the judge:

Q: Who else was in heaven with him?

A: My brother and my cousin.

Q: Okay. What's your brother's name?

A: Junior

Q: Okay. And he was there, too?

A: (Nodding.)

Q: And did you talk to Jaquari then?

A: Uh-huh.

Q: Did he say anything to you?

A: Yes.

Q: What did he say to you?

A: He . . . he said, my mommy killed my brother, and my mommy didn't.

Q: Okay. Now, I want to ask you a little bit (Id.)
The Seventh Circuit explained the importance of this testimony:

Because this account involves both of Diante's brothers, we cannot be completely certain whether the "He" in the penultimate line refers to Junior or to Jaquari. The difference bears on both the competency determination and Harris's guilt or innocence. If the speaker was Junior, Diante was describing what his surviving brother Junior had told him at the wake or funeral: Junior said that Harris had killed Jaquari, and Diante was telling the judge that was wrong. The testimony is entirely different if Diante meant that Jaquari appeared to his brothers from beyond the grave to accuse their mother of killing him. The first reading is supported by the fact that Diante said, "He said, my mommy killed my brother," not "He said, my mommy killed me," or "He said, my mommy killed him." The best support for the second reading is that Jaquari was the brother the prosecutor had last mentioned (three questions earlier), but it's safe to say that six-year-old Diante was not precise with pronouns and antecedents. Given the ambiguity, one would have expected counsel or the court to ask some follow-up questions to learn what Diante meant, at least before assuming that he was reporting a visit from beyond the grave. But nothing more was said on the subject. And not only did the court assume that this testimony referred to a communication with Jaquari's spirit, but it relied heavily on his report of this supposed "fantasy" to find that Diante was not competent to testify.

(Id. at 618-19.)

Defense counsel wanted to call Dr. Ale Levy and informed the judge that he had subpoenaed her. The doctor was not present, and ultimately defense counsel chose not to fight for a continuance to have her testify (the witness, according to the Seventh Circuit, who would have shown that Diante's recollections of what happened were consistent and credible). The prosecution called a second Child Advocacy Center investigator, Karen Wilson, who interviewed Diante the day after Levy interviewed him, to testify that Diante stated that Scooby-Doo, Spiderman, and Santa Claus were real persons.

The trial judge ruled that Diante was incompetent. The judge observed that Illinois provides only two grounds for disqualification as incompetent: inability to express oneself so as to be understood, or inability to understand the duty to tell the truth. 
The judge said that he was unpersuaded that Diante understood the duty to tell the truth. The judge also expressed doubts as to whether Diante was able to distinguish reality from fantasy. The judge therefore disqualified him on both grounds. In postconviction proceedings, the trial judge conceded error in placing the burden of showing competency on the defense but held that the same result would have obtained had the state borne the burden.

\section{Direct Appeal and the Seventh Circuit}

The Illinois Appellate Court affirmed the conviction. It found no abuse of discretion in the ruling finding Diante incompetent. Amazingly, it also held that even if the trial judge abused discretion, any error was harmless because Diante's testimony would not have influenced the verdict. The court failed to address Harris's Sixth Amendment compulsory process argument.

The Seventh Circuit described both the Sixth Amendment right of a defendant "to have compulsory process for obtaining witnesses in his favor" and the Fourteenth Amendment due process right to present a meaningful and complete criminal defense. (Id. at 626.) It summed up the law as establishing that exclusion of defense evidence abridges a defendant's constitutional rights where the restriction is arbitrary or disproportionate to the interests it is designed to serve and the evidence implicates a sufficiently weighty interest of the accused.

The Seventh Circuit found that Diante's testimony was critical, material, noncumulative, and uncontradicted. It rejected the state appellate court's analysis that Diante's testimony lacked significant probative force because he said he was asleep when Jaquari died. It also rejected the argument that Harris's videotaped confession meant that the evidence for the state was overwhelming and observed that the jury had reasons to question the reliability of the confession, including the fact that her initial confession was inconsistent with the physical evidence.

The Seventh Circuit summarized Diante's proffered testimony as follows:

Diante was by no means a perfect witness. He said that he believed Santa Claus and Spiderman were real and that he had seen Jaquari "in heaven." He also told [Child Advocacy Center] investigators Levy and Wilson that he had been asleep when Jaquari got hurt, which was superficially inconsistent with the defense's claim that Diante witnessed Jaquari's death. (Nobody asked him to explain the difference.) And he did not respond to the court's satisfaction to two of its questions: first, whether he could "remember anything else that happened that day" (he said no); and second, whether he had "spoken before with any of the people who are here today before you came to court." (Diante again said no, even though he had previously spoken to the prosecutor).

But none of these responses were explored by the court or counsel with even minimal follow-up. Had there been any, the court should have gained the same insights that Dr. Galatzer-Levy did: that Diante believed Santa and Spiderman were real to the extent they were not cartoons; that by "heaven," [Diante] probably meant "church"; that he did not realize that he witnessed Jaquari die because he did not understand death; and that he remembered many details from the day of Jaquari's death. Moreover, even if like many six-year-olds Diante believed that these mythical characters were real, such imaginings were not commingled with his memory of the day of Jaquari's death and would not have hindered his ability to tell what he saw.

(Id. at 636-37.)

The court found that the larger problem was with the trial judge's expectations of a child witness:

The bigger issue, and the trial court's more glaring failure at the competency hearing, was its unrealistic expectations for a six-year-old witness. As Illinois courts have emphasized, "[i]t is not incumbent upon a child to give perfect answers to questions asked during the competency determination or at trial to be deemed a competent witness." A child's belief in Santa Claus or Spiderman does not make the child's testimony about his real-life experiences unreliable. Nor does Diante's negative response to the court's general inquiry if he remembered anything else from the day. Such a broad, open-ended question in a hearing or deposition often confuses adults who have already been testifying about what they remember. It was unlikely to elicit a detailed, substantive account of the day's events from a six-yearold, especially when posed by a stranger in a black robe. Likewise, the trial court's question, "Have you spoken before with any of the people who are here today before you came to court?" was both compound and ambiguous enough that many adults might have trouble answering it. Was the judge asking whether Diante had ever spoken before with anyone present at court that day? Or whether he had spoken that day with anyone present before 
coming to court? And how many people were in the courtroom? The answer says nothing probative about Diante's reliability as a witness. There was no follow-up to make sure he even understood the question.

(Id. at 637-38 (footnote omitted) (citation omitted).)

The court added a footnote pointing out substantial authority supporting its observation that "[a] child's belief in Santa Claus or Spiderman does not make the child's testimony about his real-life experiences unreliable." (Id. at 637.)

The bottom line for the court was this:

If the Compulsory Process Clause is to be more than a "dead letter," it demands that courts recognize that the exclusion of defense evidence can have constitutional consequences beyond the rules of evidence. Here, state courts overlooked the Sixth Amendment significance of Diante's testimony. By disqualifying Diante from taking the stand, the trial court deprived Harris of evidence that was favorable and material to her defense, and on the evidence before it, the exclusion was "arbitrary or disproportionate" to the interests served by the competency rule. The exclusion violated Harris's right to present a complete defense under the Sixth and Fourteenth Amendments of the U.S. Constitution. (Id. at 639 (citation omitted).)

\section{Lessons}

Children do not have to be perfect witnesses to be competent to testify in a criminal trial.

When a child is a critical witness in a criminal prosecution, it is vitally important that the questions presented to the child be clear and that the child understand the questions.

When a child is the only witness to an event, it is especially important that the child's testimony be heard and that the trier of fact decide whether the child's testimony is reliable.

The fact that a defendant has confessed does not automatically mean that the confession is reliable or more important than other evidence that casts doubt on the reliability of the confession. 